\title{
Immunostimulatory properties and antitumor activities of glucans (Review)
}

\author{
LUCA VANNUCCI $^{1,2}$, JIRI KRIZAN $^{1}$, PETR SIMA $^{1}$, DMITRY STAKHEEV $^{1}$, FABIAN CAJA $^{1}$, \\ LENKA RAJSIGLOVA $^{1}$, VRATISLAV HORAK ${ }^{2}$ and MUSTAFA SAIEH ${ }^{3}$ \\ ${ }^{1}$ Laboratory of Immunotherapy, Department of Immunology and Gnotobiology, Institute of Microbiology, \\ Academy of Sciences of the Czech Republic, v.v.i., 14220 Prague 4; ${ }^{2}$ Laboratory of Tumour Biology, \\ Institute of Animal Physiology and Genetics, Academy of Sciences of the Czech Republic, v.v.i., 27721 Libechov, \\ Czech Republic; ${ }^{3}$ Department of Biology, University of Al-Jabal Al-Gharbi, Gharyan Campus, Libya
}

Received April 5, 2013; Accepted May 17, 2013

DOI: $10.3892 /$ ijo.2013.1974

\begin{abstract}
New foods and natural biological modulators have recently become of scientific interest in the investigation of the value of traditional medical therapeutics. Glucans have an important part in this renewed interest. These fungal wall components are claimed to be useful for various medical purposes and they are obtained from medicinal mushrooms commonly used in traditional Oriental medicine. The immunotherapeutic properties of fungi extracts have been reported, including the enhancement of anticancer immunity responses. These properties are principally related to the stimulation of cells of the innate immune system. The discovery of specific receptors for glucans on dendritic cells (dectin-1), as well as interactions with other receptors, mainly expressed by innate immune cells (e.g., Toll-like receptors, complement receptor-3), have raised new attention toward these products as suitable therapeutic agents. We briefly review the characteristics of the glucans from mycelial walls as modulators of the immunity and their possible use as antitumor treatments.
\end{abstract}

\section{Contents}

1. Introduction

2. $\beta$-glucan sources and properties

3. Immunostimulatory properties of glucans

4. Glucan receptors on immune cells

5. Antitumor activities of glucans

6. Conclusion and potential

Correspondence to: Dr Luca Vannucci, Laboratory of Immunotherapy, Department of Immunology and Gnotobiology, Institute of Microbiology, Academy of Sciences of the Czech Republic, v.v.i., Videnska 1083, 14220 Prague 4, Czech Republic

E-mail: vannucci@biomed.cas.cz

Key words: $\beta$-glucans, polysaccharides, immunity, immunotherapy, cancer

\section{Introduction}

Renewed interest has recently arisen for both functional foods and the investigation of the scientific value of traditional medical treatments. The evaluation of mushroom derivatives and their medical properties are important part of these studies. Polysaccharides, including the glucans, have been described as biologically active molecules (1-4). Certain glucose polymers, such as $(1 \rightarrow 3),(1 \rightarrow 6)$ - $\beta$-glucans, were recently proposed as potent immunomodulation agents (3-5). Even though glucans can be extracted from the cell walls of yeast, oat, barley, seaweeds, algae and bacteria, the foremost source of medical glucans turns out to be fungal cell walls which consist either of polysaccharides such as chitin, cellulose, $(1 \rightarrow 3)-,(1 \rightarrow 6)-\beta$-glucans and $(1 \rightarrow 3)$ - $\alpha$-glucans, or polysaccharide-protein complexes (6). The $\beta$-glucans are the most studied within these polysaccharides and are principally obtained from the fruit body of various types of mushrooms. Used especially in traditional Oriental medicine (7), they are reported to be found in fruit bodies, cultured mycelium and cultured broth from higher Basidiomycetes mushrooms (as resulted from $\sim 700$ species of investigated higher Hetero- and Homobasidiomycetes). According to traditional medicine assertions, as well as some scientific studies, glucans have been reported to produce antitumor, immunomodulating, antioxidant, radical scavenging, cardiovascular, antihypercholesterolemia, antiviral, antibacterial, antiparasitic, antifungal, detoxification, hepatoprotective and antidiabetic effects $(8,9)$. Growing interest of Western science into biologically active polysaccharides can be considered to start after the publication of Pillemer and Ecker in 1941 (10). They described a crude yeast cell wall preparation, later named zymosan, able to modulate non-specific immunity (complement) (11). It was unknown at that time which component of this preparation was stimulating the immune response. Later on, $\beta$-glucan was identified by Riggi and Di Luzio as the immune-activating compound within the components of zymosan (after testing its lipid and mannan components) (7). Since then, a large number of studies have been performed to clarify the immunomodulating potential of glucans and their possible antitumor effects (12-18). The discovery of specific receptors for glucans on immune cells, the recent advances 
in understanding host immune responses against infectious agents and cancer and the importance of the innate immunity (inflammation) in these responses have renewed the interest toward glucans as perspective immunotherapeutic molecules.

\section{2. $\beta$-glucan sources and properties}

The glucans are D-glucose-based polysaccharides. With their glucose anomeric structure, they can be $\alpha$-D-glucans, $\beta$-D-glucans and mixed $\alpha, \beta$-D-glucans. They present different types of glycosidic bonds originating either $(1 \rightarrow 3)$-, $(1 \rightarrow 6)$ - $\beta$-glucans (e.g., zymosan, laminarin, lentinan, pleuran), or $(1 \rightarrow 3)-,(1 \rightarrow 4)-,(1 \rightarrow 6)-\alpha$-glucans (e.g., dextran, glycogen, starch). Finally, depending on their constitution, they are indicated as homoglucans (only glucose molecules) or heteroglucans (not only glucose molecules) $(19,20)$.

The $\beta$-glucans consist of linear unbranched polysaccharides of $\beta$-D-glucose. The basic $\beta$-D-glucan is a repeating structure with the $\beta$-D-glucose units joined together in linear chains by $\beta$-bonds. These can extend either from carbon 1 of one saccharide ring to carbon 3 of the next $(\beta 1 \rightarrow 3)$ (Fig. 1), or from carbon 1 to carbon $4(\beta 1 \rightarrow 4)$, or from carbon 1 to carbon 6 $(\beta 1 \rightarrow 6)(1)$. The $\beta$-D-glucans can form large cylindrical molecules containing up to 250,000 glucose units.

As reported above, the sources of glucans are various, including fungi (e.g., mushrooms), yeast and seaweed, as well as barley. Medical glucans (as the ones used by traditional medicine) are principally obtained from edible fungi. By boiling and treating with enzymes from one of the cited sources, glucans can be extracted in crude form yielding soluble and insoluble products $(19,21,22)$. There are many forms of soluble $\beta$-glucans evaluated for possible antitumor activity, such as $(1 \rightarrow 3)-\beta$-D-glucan, SSG obtained from Sclerotina sclerotiorum IFO 9395 (23), SPG (also Schizophyllan, sizofiran, sonifilan) from Schizophyllum commune (24) and GRN (also Grifolan) from Grifola frondosa (25) and they often exist as a linear triple-helical structure in an aqueous solution (26). Insoluble glucans have been isolated for the first time from the mushroom Lentinus edodes (27). They were also isolated from the cell wall of yeast by using the combination of $\mathrm{NaClO}$ oxidation and dimethylsulfoxide (DMSO) extraction (28). To improve their solubility, derivatization by phosphorylation, either sulfation or amination can be used. However, insoluble $\beta$-glucans were found to possess higher immunostimulating activity than soluble ones and are administered orally. Factors that can greatly influence the antitumor and immunodulatory activities of the glucans are their structure, molecular weight, degree of branching and conformation (17,29-31). The molecular weight of glucans is dependent upon their source and extraction method (32). For example, the average molecular weight of Krestin (PSK), Lentinan, Schizophyllan (SPG) and PGG-glucan are, respectively, reported as 100,000, 500,000, 450,000 and 170,000 Da (33-35).

\section{Immunostimulatory properties of glucans}

As stated above, the immunostimulatory properties of fungal $\beta$-glucans were studied and described almost 50 years ago (36). Shortly afterwards, their effects against tumor development in experimental animals were also described (37) and finally glucans were reported to modulate other conditions (e.g., cholesterol levels, glucose tolerance) $(38,39)$.

Since these early studies, it has been demonstrated that $\beta$-D-glucans increase the resistance of mammalians against several bacterial, fungal, viral and protozoal pathogens (40-43). A recent study compared the effects of soluble oat glucan versus Pleurotan, an insoluble $\beta$-D-glucan isolated from the mushroom Pleurotus ostreatus. They were administered as a food supplement for athletes and the $\beta$-D-glucan isolated from the mushroom resulted in significantly reducing the incidence of upper respiratory tract infection. Interestingly, the Pleurotan administration was associated with an increased number of circulating natural killer cells as well as a preventive effect on the reduction of natural killer cell activity. These latter findings may explain the reduced infectivity risk in the treated athletes (29). Since the soluble oat glucan supplementation did not produce effects on the incidence of respiratory tract infections, it was suggested that solubility and structural factors (e.g., backbone structure and degree of branching) can deeply affect the immunomodulatory capacity of $\beta$-D-glucans (17). Many studies have reported the ability of $(1 \rightarrow 3)-\beta-D$-glucans to activate innate immunity with effects also on adaptive immunity, inducing humoral and cell-mediated immune responses. The $(1 \rightarrow 3)-\beta$-D-glucans were found to increase the antimicrobial activity of mononuclear cells and neutrophils $(7,44,45)$ and enhance the functional activity of macrophages $(46,47)$. It has been reported that the (1-6)-branched type glucans, with high molecular weight and $(1 \rightarrow 3)-\beta$-D-glucans are especially effective in inducing nitric oxide production by macrophages $(21,47,48)$. Moreover, ex vivo experiments with macrophages obtained from animals treated with $(1 \rightarrow 3)-\beta$-D-glucans showed enhanced esterase release and cytostatic effect on tumor cells when challenged with L-929 tumor cells $(49) .(1 \rightarrow 3)-\beta$-D-glucans were also reported to have hematopoietic activities, according to their conformation (single and triple helix) and to stimulate the proliferation of monocytes and macrophages (50-52). Relating to their role in triggering innate immunity responses, insoluble and derivatized $(1 \rightarrow 3)-\beta$-D-glucans, according to their source, were also found to stimulate the production of proinflammatory molecules such as complement components, IL- $1 \alpha / \beta$, TNF- $\alpha$, IL- 2, IFN- $\gamma$ and eicosanoids as well as IL-10, and IL-4 (53-59).

Protective effects of glucans were observed in mouse and rat models of sepsis (60-62). Neutrophils obtained from glucan-treated mice showed enhanced phagocytosis of E. coli in ex vivo experiments (63). In vivo administration of poly-[1-6]- $\beta$-D-glucopyranosyl-[1-3]- $\beta$-D-glucopyranose (PGG-glucan) in rats before bacterial challenge increased the number of leukocytes and also protected against lethal peritonitis (64). Similarly, in a mouse model of dental infection, PGG-glucan reduced infection-stimulated periapical bone resorption (65). The immunomodulatory properties of PGG-glucan studied also in many in vitro models evidenced that phagocytic cells (polymorphonuclear lymphocytes) increase their bactericidal capabilities when incubated in the presence of PGG-glucans. In purified human neutrophils, PGG-glucan was shown to induce the activation of an NF $\kappa$ B-like nuclear transcription factor. This activation was dependent on the binding of PGG-glucan to glycosphingolipid lactosylceramide expressed on the cell surface of neutrophyls 


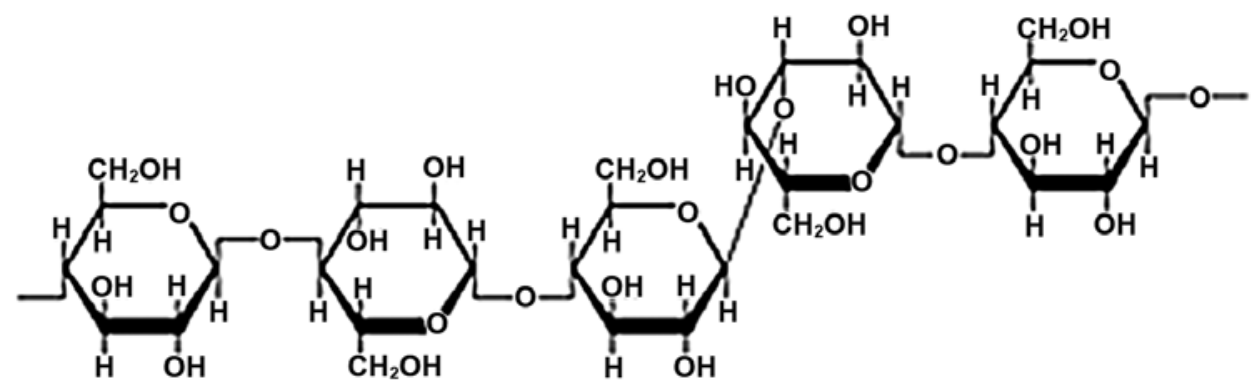

Figure 1. Example of $(1 \rightarrow 3)-\beta-D$-glucan.

(45). Berovic et al reported that one polysaccharide fraction isolated from Ganoderma lucidum, a mushroom rich in $\beta$-D-glucans, can induce TNF- $\alpha$ synthesis in primary cultures of human peripheral blood mononuclear cells (66). However, the protective effect of $\beta$-glucan against oxidative stress was also described using $(1 \rightarrow 3)-,(1 \rightarrow 6)-\beta$-D-glucan prepared from Saccharomyces cerevisiae yeast (62). These data support the observations of the ability of glucans to prevent and decrease infectious complications $(53,67)$. Nevertheless, the various effects reported here indicate the necessity of a clear characterization of glucans by their origin, their structure and their fractions to better define the type of immune modulation elicited by each compound.

\section{Glucan receptors on immune cells}

The innate immunity cells are provided of a complex network of germ line-encoded pattern-recognition receptors (PRRs). They can identify pathogens by binding to carbohydrates, lipids and proteins expressed by the microorganism, including fungi (68-71). As reported above, in vivo administration of pure glucans induces the activation a wide range of responses by innate immunity $(70,72)$. In particular, glucans have been found to react with one or multiple of the following cell surface receptors: complement receptor-3 (CR3), lactosylceramides, scavenger receptors and dectin-1 (73-76). Dectin-1 is considered the main $\beta$-D-glucan receptor. The $\beta$-D-glucan binding to myeloid cell receptors triggers, according to the bound receptor, a series of signaling events that modulate innate and subsequently adaptive immune responses, mainly through release of pro-inflammatory cytokines (IL- $1 \alpha / \beta$, IL- 6 , IL-8, IL-12, TNF- $\alpha$ ) as well as cytotoxic molecules working also as inflammatory mediators [nitric oxide (NO) and hydrogen peroxide $\left(\mathrm{H}_{2} \mathrm{O}_{2}\right)$ ], as cited in the previous paragraph. The activation of macrophages performed by $(1 \rightarrow 3)-\beta$-D-glucans is thought to be consequent to binding of the polymer to CR3 (CD11/CD18) receptors (42). The receptor-glucan interaction triggers phagocytosis, respiratory burst and secretion of cytokines such as TNF- $\alpha$ in addition to IL-10 $(77,78)$. For an adequate use of glucans as immune enhancers, it is necessary to point out that glucan polymers derived from various sources can largely differ in binding affinity with specific receptors (from $24 \mu \mathrm{M}$ to $11 \mathrm{nM}$ ). Consequently, different biological effects can be promoted according to the source of the chosen molecule (68). Human monocytes (but also fibroblasts) express many glucan receptors which can differentiate between the polymers of $(1 \rightarrow 3)-\beta$-D-glucan $(68,79)$. Neutrophils exhibit lactosylceramide that mediates the response to PGG-glucan and CR3 mediates cytotoxicity for iC3b-opsonized target cells $(35,80)$. CR3 receptor is also represented on natural killer cells $(\mathrm{NK})$. Consequently, the triggering of complement alternative activation pathway by $\beta$-D-glucans with the availability of $\mathrm{iC} 3 \mathrm{~b}$ fragment elicits a high-avidity link of iC3b-opsonized cells (tumor cells or pathogens) to the receptors for $\mathrm{iC} 3 \mathrm{~b}$ and stimulates phagocytosis by monocytes and cytotoxic degranulation by NK cells (81). Macrophage/monocytes present on their surface scavenger receptors and dectin- 1 recognizing $(1 \rightarrow 3)-\beta$-D-glucans and non-opsonic zymosan. Dectin-1 is also represented on dendritic cells (see below) $(82,83)$.

Some studies have suggested the complement receptor type 3 (CR3, also CD11b/CD18) is a prime candidate for $\beta$-D-glucan receptor on human monocytes, neutrophils and NK cells (80). More recently, dectin-1 was definitively identified as the most important $\beta$-D-glucan receptor (84). Human and murin dectin-1 mostly show a similar structure and function (85). Dectin-1 is a small type II transmembrane glycoprotein receptor containing one lectin-like carbohydrate recognition domain which is able to recognize $(1 \rightarrow 3)-\beta$ - and/or $(1 \rightarrow 6) \beta$-D-glucans as well as fungi particles (86). This receptor is highly expressed on macrophages and granulocytes, but also on dendritic cells with effects on $\mathrm{T}$ and $\mathrm{B}$ cell responses $(75,87,88)$. Dectin-1 presents two ligand-binding sites, one able to recognize the endogenous ligand on $\mathrm{T}$ cells and the other for exogenous carbohydrate (89). It has been shown that dectin-1 is able to mediate inflammatory cellular responses to $\beta$-D-glucans. The release of TNF- $\alpha$, after interaction of $\beta$-D-glucans with the superficial part of the receptor, needs the cytoplasmic tail and immunoreceptor tyrosine activation motif of Dectin-1 as well as Toll-like receptor (TLR)-2 and Myd88 $(71,73,90,91)$. The role of dectin-1 is important on dendritic cells (DCs) (73,75). Recent studies have shown the capability of DCs to stimulate antigen specific $\mathrm{CD}^{+} \mathrm{T}$ cell responses after dectin-1 is bound by the anti-dectin- 1 antibody. The receptor-Ab interaction triggers a Syk-dependent pathway with upregulation of costimulatory molecules, secretion of cytokines and chemokines. This induces enhancement of antigen presentation, priming and expansion of antigen specific $\mathrm{CD}^{+}$ $\mathrm{T}$ cells. A similar effect can be hypothesized after dectin-1 bounding to $\beta$-glucans (92).

Moreover, glucan-dependent dectin-1 signaling in macrophages and bone marrow-derived dendritic cells has been 
found to trigger the formation of LC3II, a central component in autophagy, as well as recruitment of LC3II to phagosomes. Here also Syk is involved. This promoted presentation of fungal-derived antigens to CD4 T cells occurs by facilitation of MHC class II molecule recruitment to phagosomes $(93,94)$.

\section{Antitumor activities of glucans}

Polysaccharides from fruiting bodies, cultured mycelia and cultured filtrates of basidiomycetes have been reported to present antitumor activity. These antitumor polysaccharides are different in their chemical composition depending on their molecular weight, purity and degree of branches $(3,82)$. As quoted by Bulmer et al (95), the first reports on the antitumor properties of extracts from fungi were published by Ringler in 1955 (a PhD thesis) and Lukas et al (96). Since then, many antitumor polysaccharides were isolated from fungi and extensively studied, especially in Japan (12,17,97-99). As has been emphasized, the therapeutic efficacy of these polysaccharides can greatly differ according to their chemical composition, configuration and physical properties. A wide range of glucans extending from homopolymers to highly complex heteropolymers were found to exhibit antitumor activity and most of the antitumor polysaccharides presented the same basic $\beta$-D-glucan structure with different types of glycosidic bounds. Glucans with high molecular weight appear to be more effective than those with low molecular weight $(3,99)$. Differences in the effectiveness of mushroom glucan preparations are related to the type of polymer (according to the type of $\beta$-backbone) but also to the presence and proportion of various products in the same preparation. The simultaneous presence of different products may elicit multiple stimulatory activities with possible enhancement of the immunomodulatory effects. A clear example of this possible collaboration, related to products obtained from Agaricus blazei, is reported by Borchers et al in their review on mushrooms as anticancer immune modulators (100). They assert that the mushroom Agaricus blazei contains more compounds [an antitumor glucan with a $(1 \rightarrow 6)-\beta$-backbone, an $(1 \rightarrow 6)-\alpha$ - and $(1 \rightarrow 4)$ - $\alpha$-D-glucan complex and a glucomannan with a main chain of $(1 \rightarrow 2) \beta$-linked D-mannopyranosyl residues] that were found to inhibit tumorigenesis (101-103). The preparation by aqueous extraction from powdered, dry fruiting body was less efficient than the direct administration of the complete dry powdered form. In rats fed with either aqueous extract or dry powdered preparation, the complete dry powder developed a better antimutagenic activity (104). Similar results were found also for diets containing powdered Lentinula edodes (shiitake) $(105,106)$. The interpretation of Borchers et al is that different polysaccharides can cooperate by targeting different cell subsets by different receptors. Consequently, a more complex and effective stimulation would be more easily elicited when whole-mushroom extracts are used (100,102,107-109).

Polysaccharides or polysaccharide-protein complexes obtained from natural sources are generally reported to not produce direct cytotoxic action on tumor cells, but to induce host-mediated antitumor immune responses. However, the complete absence of direct effects on tumor cells cannot be totally excluded according to some recent studies (110-112). Pioneering studies of Di Luzio et al, using intravenous injec- tion of soluble or particulate glucan, documented significant regressions of a syngeneic anaplastic mammary carcinoma and B16F10 melanoma in A/J and C57BL/6 mice, respectively (113). It has also been demonstrated that orally administrated yeast-derived as well as mushroom-derived $\beta-(1-3)$ glucan had significant inhibitory effects on the growth of metastatic cancer cells using in vivo models of cancer $(114,115)$. Animals that received treatment with PSK, $\beta$ - $(1 \rightarrow 4)$-D-glucans with $(1 \rightarrow 6)$ - $\beta$-glycopyranosidic side chains showed an increased number of neutrophils and a significant decrease in the size and number of lung metastasis (116). Therefore, the effects may not be limited only for use in the early stages of carcinogenesis or tumor development as suggested by the enhancement of immune responses (IL- $1 \beta$, IFN- $\gamma$, TNF- $\alpha$ and IL- 12 production, $\mathrm{NK}$ cell increase, macrophages activation), an increase of the host's antioxidant capacity and upregulation of phase I and phase II enzymes involved in the metabolic transformation as well as detoxification of mutagenic compounds $(117,118)$. Finally, the efficacy of some types of fungal derivatives like lentinan, pachymaran, scleroglucan, curdland, grifolan and Agaricus blazei $(1 \rightarrow 3)-\beta-\mathrm{D}$-glucan resulted particularly high in various in vivo models of cancer. According to the reports, the tumor inhibition ratio in animal models range from 90.4 (scleroglucan) to $99.6 \%$ (lentinan) (119-122).

Glucans have also been proposed as an adjuvant. Some examples in animal models suggest an increasing of chemo- or immunotherapy efficacy when they are associated to polysaccharides, mainly glucans. The combination of an anti-MUC1 $\mathrm{mAb}$ with $\beta$-glucans significantly increased $20 \%$ the rate of RMA-S-MUC1 tumor regression in C57BL/6 mice (14). Ganoderma lucidum polysaccharides were also able to prolong the survival of Lewis carcinoma bearing C57BL/6 mice and to enhance antitumor activities of cytotoxic drugs and immunomodulators (123). Of particular interest is the possibility of using glucans for triggering complement-dependent antitumor cytotoxicity.

As previously cited, complement is a relevant mediator of antitumor $\beta$-D-glucan effects even after oral administration. Complement is an important part of the innate immunity against microorganisms that exhibit $\beta$-D-glucans as a surface component. These molecules are not expressed by tumor cells and, consequently, tumor cells cannot trigger CR3-dependent cellular cytotoxicity (CR3-DCC) (124). Oral administration of $\beta$-D-glucans may modify this condition. Glucan, in insoluble form, can be processed by gastrointestinal macrophages to soluble form. Once the soluble form is delivered, it can reach CR3 of bone marrow granulocytes and tissue macrophages making iC $3 b$ fragments available. In this way, the promotion of cytotoxity against tumor cells could be the result of contemporary presence of $\mathrm{iC} 3 \mathrm{~b}$ fragments and antitumor antibodies (125). Complement activation and deposition of iCR3 on tumor cells needs the presence of antitumor antibodies to produce a synergistic effect. Such an effect, leading to tumor regression, was evidenced by various authors using administration of $\beta$-D-glucans together with monoclonal antibodies against GD2 ganglioside, G250 protein, CD20 protein, respectively in experimental neuroblastoma, carcinoma and CD20+ lymphoma (126-128). Evidence of the dependence of this approach from complement involvement was given by failures of therapy in mice deficient in $\mathrm{CR} 3\left(\mathrm{CD} 11 b^{-/-}\right)$or $\mathrm{C} 3$ 
$\left(\mathrm{C3}^{--}\right)$(129-131). This approach, since the progressively larger use of monoclonal antibodies in anticancer therapies, results in a particularly appealing and prospective application of $\beta$-D-glucans as effective enhancers of antitumor responses, as also demonstrated by recent literature $(18,132)$.

\section{Conclusion and potential}

A substantial amount of literature has been accumulated in past decades on the medical potential of polysaccharides, particularly the $\beta$-D-glucans, from medical mushrooms used by the traditional medicine. Especially in recent years, the interest in these molecules or compounds has arisen together with the understanding of innate immunity implications during carcinogenesis and cancer development. Unfortunately, many clinical reports lack a specific rationale or simply describe effects according to traditional medicine application. However, some recent studies on gastric and colorectal cancer patients indicate the possible efficacy of these saccharides (133-135). Experimental studies have in large part clarified the basic mechanisms involved in the immune stimulation produced by $\beta$-D-glucans, especially with the knowledge on dectin-1 and C3-iCR3 involvement. A clear definition of the biologically active molecules and a more detailed chemical and biological characterization of the glucans from different sources appear necessary to better define the rationale of their application in anticancer therapies as well as other suitable pathologies. For example, it was suggested by Hamuro and Chihara that only extracts able to deactivate protein helices (as tested on bovine serum albumin) were active against tumors (136). Furthermore, $\beta$-D-glucans also appear suitable for use in nanomedicine for preparation of natural nanocarriers for drug or biological molecule delivery (137-139). The creation of gels or lattices based on $\beta$-D-glucans has also been proposed for various utilizations (e.g., in wound healing by stimulating macrophage activation and collagen deposition) $(140,141)$. The addition of new areas of application, apart from the immunological use in oncology, opens new interesting perspectives and makes the study of $\beta$-D-glucan chemical and biological properties a prospective field of research.

\section{Acknowledgements}

We thank the support of: ARPA Foundation, Pisa, (IT), RVO 61388971 and RVO 67985904 (CZ).

\section{References}

1. Tzianabos A: Polysaccharide immunomodulators as therapeutic agents: structural aspects and biologic function. Clin Microbiol Rev 13: 523-533, 2000.

2. Han SB, Lee CW, Jeon YJ, Hong ND, Yoo ID, Yang KH and Kim HM: The inhibitory effect of polysaccharides isolated from Phellinus liteus on tumor growth and metastasis. Immunopharmacology 41: 157-164, 1999.

3. Ooi VE and Liu F: Immunomodulation and anticancer activity of polysaccharide-protein complex. Curr Med Chem 7: 715-729, 2000.

4. Falch BH, Espevik T, Ryan L and Stokke BT: The cytokine stimulating activity of $(1 \rightarrow 3)$-beta-D-glucans is dependent on the triple helix conformation. Carbohydr Res 329: 587-596, 2000.

5. Barsanti L, Passarelli V, Evangelista V, Frassanito AM and Gualtieri P: Chemistry, physico-chemistry and applications linked to biological activities of $\beta$-glucans. Nat Prod Rep 28 457-466, 2011.
6. Yap AT and Ng ML: An improved method for the isolation of lentina from the edible and medicinal shiitake mushroom, Lentinus edodes (Berk.) Sing. (Agaricomycetideae). Int J Med Mushr 3: 6-19, 2001

7. Riggi SJ and Di Luzio NR: Identification of a reticuloendothelial stimulating agent in zymosan. Am J Physiol 200: 297-300, 1961.

8. Wasser SP: Current findings, future trends and unsolved problems in studies of medicinal mushrooms. Appl Microbiol Biotechnol 89: 1323-1332, 2011

9. Chang ST and Wasser S: The role of culinary-medicinal mushrooms on human welfare with a pyramid model for human health. Int J Med Mushr 14: 95-134, 2012.

10. Pillemer L and Ecker EE: Anticomplementry factor in fresh yeast. J Biol Chem 137: 139-142, 1941.

11. Pillemer L, Blum L, Pensky J and Lepow IH: The requirement for magnesium ions in the inactivation of the third component of human complement (C'3) by insoluble residues of yeast cells (zymosan). J Immunol 71: 331-338, 1953.

12. Ohano N, Miura NN, Nakajima M and Yadomae T: Antitumor 1,3-beta-glucan from cultured fruit body of Sparassis crispa. Biol Pharm Bull 7: 866-872, 2000.

13. Novak M and Vetvicka V: Glucans as biological response modifiers. Endocr Metab Immune Disord Drug Targets 9: 67-75, 2009.

14. Hong F, Hansen RD, Yan J, Allendorf DJ, Baran JT, Ostroff CR and Ross GD: Beta-glucans functions as an adjuvant for monoclonal antibody immunotherapy by recruiting tumoricidal granulocytes as killer cells. Cancer Res 63: 9023-9031, 2003.

15. Kamiryo Y, Yajima T, Saito K, Nishimura H, Fushimi T, Ohshima Y, Tsukamoto Y, Naito S and Yoshikai Y: Soluble branched $(1,4)-\beta$-D-glucans from Acetobacter species enhance antitumor activitiese against MHC class I-negative and postitive malignant melanoma through augmented NK activity and cytotoxic T-cell response. Int J Cancer 115: 769-776, 2005.

16. Ryoyama K, Kidachi Y, Yamaguchi H, Kajiura $\mathrm{H}$ and Takata H: Antitumor activity of an enzymatically synthesized $\alpha-1,6$ branched $\alpha-1,4$-glucan, glycogen. Biosci Biotechnol Biochem 68: 2332-2340, 2004.

17. Chan GC, Chan WK and Sze DM: The effects of beta-glucan on human immune and cancer cells. J Hematol Oncol 2: 25, 2009.

18. Aleem E: $\beta$-glucans and their applications in cancer therapy: focus on human studies. Anticancer Agents Med Chem: Nov 5, 2012 (Epub ahead of print).

19. Usui S, Tomono Y, Sakai M, Kiho T and Ukai S: Preparation and antitumor activities of beta- $(1 \rightarrow 6)$ branched $(1 \rightarrow 3)$-beta-D-glucan derivatives. Biol Pharm Bull 18: 1630-1636, 1995.

20. Synytsya A and Novák M: Structural diversity of fungal glucans. Carbohydr Polym 92: 792-809, 2013.

21. Sawai M, Adachi Y, Kanai M, Matsui S and Yadomae T: Extraction of conformationally stable (1-6)-branched (1-3)$\beta$-D-glucans from premixed edible mushroom powders by cold alkaline solution. Int J Med Mushr 4: 197-205, 2002.

22. Kitamura S, Hori T, Kurita K, Takeo K, Hara C, Itoh W, Tabata K, Elgsaeter A and Stokke BT: An antitumor, branched (1 $\rightarrow 3)$-betaD-glucan from a water extract of fruiting bodies of Cryptoporus volvatus. Carbohydr Res 263: 111-121, 1994.

23. Ohno N, Kurachi K and Yadomae T: Antitumor activity of a highly branched (1-3)-beta-D-glucan, SSG, obtained from Sclerotinia sclerotiorum IFO 9395. J Pharmacobiodyn 10: 478-486, 1987.

24. Fujimoto S, Furue H, Kimura T, Kondo T, Orita K, Taguchi T, Yoshida $\mathrm{K}$ and Ogawa N: Clinical outcome of postoperative adjuvant immunochemotherapy with sizofiran for patients with resectable gastric cancer: a randomised controlled study. Eur J Cancer 27: 1114-1118, 1991.

25. Ishibashi K, Miura NN, Adachi Y, Ohno N and Yadomae T: Relationship between solubility of grifolan, a fungal 1,3-beta-Dglucan and production of tumor necrosis factor by macrophages in vitro. Biosci Biotechnol Biochem 65: 1993-2000, 2001.

26. Blecher P and Mackin W: Betafectin PGG-glucan: a novel carbohydrate immunodulator with anti-infective properties. J Biotechnol Healthcare 2: 207-222, 1995.

27. Chihara G, Maeda Y, Hamuro J, Sasaki T and Fukuoka F: Inhibition of mouse sarcoma 180 by polysaccharides from Lentinus edodes. Nature 222: 687-696, 1969.

28. Ohno N, Uchiyama M, Tsuzuki A, Tokunaka K, Miura NN, Adachi Y, Aizawa MW, Tamura H, Tanaka S and Yadomae T: Solubilization of yeast cell-wall $\beta$-(1-3)-D-glucans by sodium hypochlorite oxidation and dimethyl sulfoxide extraction. Carbohydr Res 316: 161-172, 1999. 
29. Majtan J: Pleuran ( $\beta$-Glucan from Pleurotus ostreatus): an effective nutritional supplement against upper respiratory tract infections? Med Sport Sci 59: 57-61, 2013.

30. Volman JJ, Helsper JP, Wei S, Baars JJ, van Griensven LJ, Sonnenberg AS and Plat J: Effects of mushroom-derived betaglucan-rich polysaccharide extracts on nitric oxide production by bone marrow-derived macrophages and nuclear factor-kappaB transactivation in Caco-2 reporter cells: can effects be explained by structure? Mol Nutr Food Res 54: 268-276, 2010.

31. Zhang P, Zhang L and Cheng S: Chemical structure and molecular weights of $\alpha-(1,3)$-D-glucan from Lentinus edodes. Biosci Biotechnol Biochem 63: 1197-1202, 1999.

32. Brown GD and Gordon S: Fungal $\beta$-glucans and mammalian immunity. Immunity 19: 311-315, 2003.

33. Sasaki T and Takasuka N: Further study of the structure of lentinan, an antitumor polysaccharide from Lentinus edodes. Carbohydr Res 47: 99-104, 1976.

34. Zhang M, Cui SW, Cheung PCK and Wang Q: Antitumor polysaccharides from mushrooms: a review on their isolation process structural characteristics and antitumor activity. Trends Food Sci Technol 18: 4-19, 2007.

35. Zimmerman JW, Lindermuth J, Fish PA, Palace GP, Stevenson TT and DeMong DE: A novel carbohydrate-glycosphingolipid interaction between a beta-(1-3)-glucan immunomodulator PGG-glucan and lactosylceramide of human leukocytes. J Biol Chem 273: 22014-22020, 1998.

36. Zimmermann G and Krueger K: Ultracentrifuge studies on properdin sera of zymosan-vaccinated cattle, rabbits, guinea pigs, rats and mice and on bovine properdin serum fractions. Acta Biol Med Ger 11: 902-917, 1963 (In German).

37. Cassone A, Bistoni F, Cenci E, Pesce CD, Tissi L and Marconi P Immunopotentiation of anticancer chemotherapy by Candida albicans, other yeasts and insoluble glucan in an experimental lymphoma model. Sabouraudia 20: 115-125, 1982.

38. Haggård L, Andersson M and Punga AR: $\beta$-glucans reduce LDL cholesterol in patients with myasthenia gravis. Eur J Clin Nutr 67: 226-227, 2013

39. Zhang Y, Xia L, Pang W, Wang T, Chen P, Zhu B and Zhang J: A novel soluble $\beta-1,3$-d-glucan Salecan reduces adiposity and improves glucose tolerance in high-fat diet-fed mice. Br J Nutr 13: $1-9,2012$

40. Di Luzio NR: Update on the immunomodulating activities of glucans. Springer Semin Immunopathol 8: 387-400, 1985.

41. Di Luzio NR: Immunopharmacology of glucan: a broadspectrum enhancer of host defence mechanisms. Trends Pharmacol Sci 4 344-347, 1983.

42. Kaneko Y and Chihara G: Potentiation of host resistance against microbal infections by lentinan and its related polysaccharides. In: Microbal Infections: Role of Biological Response Modifers. Friedman H, Klein TW and Yamaguchi H (eds). Plenum Press, New York, NY, pp201-215, 1992.

43. Williams DL, Browder IW and Di Luzio NR: Immunotherapeutic modification of Escherichia coli-induced experimental peritonitis and bacteremia by glucan. Surgery 93: 448-454, 1983.

44. Ling J, Melican D, Cafro L, Palace G, Fisette L, Armstrong R and Patchen ML: Enhanced clearance of a multiple antibiotic resistance Staphilococcus aureus in rats treated with PGG-glucans is associated with increased leukocyte counts and increased neutrophil oxidative burst activity. Int J Immunopharmacol 20 : 595-614, 1998.

45. Wakshull E, Brunke-Reese D, Lindermuth J, Fisette L, Nathans RS, Crowley JJ, Tufts JC, Zimmerman J, Mackin W and Adams DS: PGG-glucan, a soluble beta-(1,3)-glucan, enhances the oxidative burst response, microbicidal activity and activates an NF-kappa B-like factor in human PMN: evidence for a glycosphingolipid beta-(1,3)-glucan receptor. Immunopharmacology 41: 89-107, 1999.

46. Burgaletta C, Territo MC, Quan SG and Golde DW: Glucan activated macrophages: functional characteristics and surface morphology. J Reticuloendothel Soc 23: 195-104, 1978.

47. Chanput W, Reitsma M, Kleinjans L, Mes JJ, Savelkoul HF and Wichers HJ: $\beta$-glucans are involved in immune-modulation of THP-1 macrophages. Mol Nutr Food Res 56: 822-833, 2012.

48. Adachi Y, Ohno N, Ohsawa S and Yadomae T: Change biological activities of (1-3)-beta-D-glucan from Grifola frondosa upon molecular weight reduction by heat treatment. Chem Pharm Bull (Tokyo) 38: 477-481, 1990.

49. Selijelid R, Bogwald J, Rasmussen LT, Larm O, Hoffman J, Berge A and Ugelstad J: In vivo activation of mouse macrophages with beta-1,3-D-glucan-derivatized plastic beads. Scand J Immunol 6: 601-605, 1985 .
50. Patchen ML and Lotzova E: Modulation of murine hemopoiesis by glucans. Exp Hematol 8: 409-422, 1980

51. Hofer $\mathrm{M}$ and Pospíšil $\mathrm{M}$ : Modulation of animal and human hematopoiesis by $\beta$-glucans: a review. Molecules 16: 7969-7979, 2011.

52. Tsuzuki A, Tateishi T, Ohno N, Adachi Y and Yadomae T: Increase of hematopoietic responses by triple or single helical conformer of an antitumor $(1 \rightarrow 3)$-beta-D-glucan preparation, Sonifilan, in cyclophosphamide-induced leukopenic mice. Biosci Biotechnol Biochem 63: 104-110, 1999.

53. Browder W, Williams D, Preutes H, Olivero G, Enrichens F, Mao P and Franchello A: Beneficial effect of enhanced macrophage function in the trauma patient. Ann Surg 211: 605-613, 1990.

54. Czop JK and Austen KF: Generation of leukotrienes by human monocytes upon stimulation of their beta-glucan receptor during phagocytosis. Proc Natl Acad Sci USA 82: 2751-2755, 1985

55. Goodridge HS, Wolf AJ and Underhill DM: Beta-glucan recognition by the innate immune system. Immunol Rev 230: 38-50, 2009.

56. Czop JK and Austen KF: Properties of glycans that activate the human alternative complement pathway and interact with human monocyte beta-glucan receptor. J Immunol 135: 3388-3393, 1985.

57. Doita M, Rasmussen LT, Seljelid R and Lipsky PE: Effect of soluble aminated beta-1,3-D-polyglucose on human monocytes: stimulation of cytokine and prostaglandin E2 production but not antigen-presenting function. J Leukoc Biol 49: 342-351, 1991.

58. Konopski Z, Seljelid R and Eskeland T: Cytokines and PGE2 modulate the phagocytic function of beta-glucan receptor in macrophages. Scand J Immunol 37: 587-592, 1993.

59. Volman JJ, Ramakers JD and Plat J: Dietary modulation of immune function by beta-glucans. Physiol Behav 94: 276-284, 2008.

60. Senoglu N, Yuzbasioglu MF, Aral M, Ezberci M, Kurutas EB, Bulbuloglu E, Ezberci F, Oksuz H and Ciragil P: Protective effects of $\mathrm{N}$-acetylcysteine and beta-glucan pretreatment on oxidative stress in cecal ligation and puncture model of sepsis. J Invest Surg 21: 237-243, 2008.

61. Bedirli A, Kerem M, Pasaoglu H, Akyurek N, Tezcaner T, Elbeg S, Memis L and Sakrak O: Beta-glucan attenuates inflammatory cytokine release and prevents acute lung injury in an experimental model of sepsis. Shock 27: 397-401, 2007.

62. Sener G, Toklu H, Ercan F and Erkanli G: Protective effect of beta-glucan against oxidative organ injury in a rat model of sepsis. Int Immunopharmacol 5: 1387-1396, 2005.

63. Williams DL, Sherwood ER, Browder IW, McNamee RB, Jones EL, Rakinic J and DiLuzio NR: Effect of glucan on neutrophil dynamics and immune function in Escherichia coli peritonitis. J Surg Res 44: 54-61, 1988

64. Onderdonk AB, Cisneros RL, Hinkson PL and Ostroff GR: Antiinfective effect of poly $\beta 1-6$ glucotriosyle- $\beta 1-3$ glucopyranose glucan in vivo. Infect Immun 60: 1642-1647, 1992.

65. Stashenko P, Wang CY, Riley E, Wu Y, Ostroff G and Niederman R: Reduction of infection-stimulated periapical bone resorption by the biological response modifier PGG-glucan. J Dent Res 74: 323-330, 1995.

66. Berovic M, Habijanic J, Zore I, Wraber B, Hodzar D, Boh B and Pohleven F: Submerged cultivation of Ganoderm lucidum biomass and immunostimulatory effects of fungal polysaccharides. J Biotecnol 103: 77-86, 2003

67. Dellinger EP, Babineau TJ, Bleicher P, Kaiser AB, Seibert GB, Postier RG, Vogel SB, Norman J, Kaufman D, Galandiuk S and Condon RE: Effect of PGG-glucan on the rate of serious postoperative infection or death observed after high-risk gastrointestinal operations. Betafectin Gastrointestinal Study Group. Arch Surg 134: 977-983, 1999.

68. Mueller A, Raptis J, Rice PJ, Kalbffleisch JH, Stout RD, Ensley HE, Browder W and Williams DL: The influence of glucan polymer structure and solution conformation on binding to (1-3)- $\beta$-D-glucans receptors in human monocyte-like cell line. Glycobiology 10: 339-346, 2000.

69. Williams DL, Mueller A and Browder W: Glucan-based macrophages stimulators: a review of their anti-infective potential. Clin Immunother 5: 392-399, 1996.

70. Hardison SE and Brown GD: C-type lectin receptors orchestrate antifungal immunity. Nat Immunol 13: 817-822, 2012.

71. Saijo $S$ and Iwakura Y: Dectin-1 and Dectin-2 in innate immunity against fungi. Int Immunol 23: 467-472, 2011.

72. Kapetanovic R and Cavaillon JM: Early events in innate immunity in the recognition of microbial pathogens. Expert Opin Biol Ther 7: 907-918, 2007. 
73. Tsoni SV and Brown GD: beta-glucans and dectin-1. Ann NY Acad Sci 1143: 45-60, 2008.

74. Murphy EA, Davis JM and Carmichael MD: Immune modulating effects of $\beta$-glucan. Curr Opin Clin Nutr Metab Care 13: 656-661, 2010.

75. Albeituni SH and Yan J: The effects of $\beta$-glucans on dendritic cells and implications for cancer therapy. Anticancer Agents Med Chem: Oct 18, 2012 (Epub ahead of print).

76. Józefowski S, Yang Z, Marcinkiewicz J and Kobzik L: Scavenger receptors and $\beta$-glucan receptors participate in the recognition of yeasts by murine macrophages. Inflamm Res 61: 113-126, 2012.

77. Chen JT and Hasumi K: Activation of peritoneal macrophages in patients with gynecological malignancies by sizofiran and recombinant interferon-gamma. Biotherapy 6: 189-194, 1993

78. Kelly EK, Wang L and Ivashkiv LB: Calcium-activated pathways and oxidative burst mediate zymosan-induced signaling and IL-10 production in human macrophages. J Immunol 184: 5545-5552, 2010

79. Kougias P, Wei D, Rice PJ, Ensley HE, Kalbfleisch J, Williams DL and Browder IW: Normal human fibroblasts express pattern recognition receptors for fungal $(1 \rightarrow 3)$-beta-D-glucans. Infect Immun 69: 3933-3938, 2001.

80. Vetvicka V, Thornton BP and Ross GD: Soluble $\beta$-glucan polysaccharide binding to the lectin site of neutrophil or natural killer cell complemet receptor type $3(\mathrm{CD} 11 \mathrm{~b} / \mathrm{CD} 18)$ generates a primed state of the receptor capable of mediating cytotoxicity of iC3b-opsonized target cells. J Clin Invest 98: 50-61, 1998.

81. Ross GD, Vetvicka V, Yan J, Xia Y and Vetvickova J: Therapeutic intervention with complement and beta-glucan in cancer. Immunopharmacology 42: 61-74, 1999.

82. Rice PJ, Kelley JL, Kogan G, Ensley HE, Kalbfleisch JH, Browder IW and Williams DL: Human monocyte scavenger receptors are pattern recognition receptors for $(1 \rightarrow 3)$-beta-Dglucans. J Leukoc Biol 72: 140-146, 2002

83. Brown GD, Taylor PR, Reid DM, Willment JA, Williams DL, Martinez-Pomares L, Wong SY and Gordon S: Dectin-1 is a major beta-glucan receptor on macrophages. J Exp Med 196: 407-412, 2002

84. Ariizumi K, Shen GL, Shikano S, Xu S, Ritter R III, Kumamoto T, Edelbaum D, Morita A, Bergstresser PR and Takashima A: Identification of a novel, dendritic cell-associated molecule, dectin-1, by subtractive cDNA cloning. J Biol Chem 275: 20157-20167, 2000

85. Willment JA, Gordon S and Brown GD: Characterization of the human beta-glucan receptor and its alternatively spliced isoforms. J Biol Chem 276: 43818-43823, 2001.

86. Brown GD and Gordon S: Immune recognition: a new receptor for beta-glucans. Nature 413: 36-37, 2001.

87. Taylor PR, Brown GD, Reid DM, Willment JA, MartinezPomares L, Gordon S and Wong SY: The beta-glucan receptor, dectin-1, is predominantly expressed on the surface of cells of the monocyte/macrophage and neutrophil lineages. J Immunol 169 3876-3882, 2002.

88. Agrawal S, Gupta S and Agrawal A: Human dendritic cells activated via dectin-1 are efficient at priming Th17, cytotoxic CD8 T and B cell responses. PLoS One 5: e13418, 2010.

89. Ozment-Skelton TR, Goldman MP, Gordon S, Brown GD and Williams DL: Prolonged reduction of leukocyte membraneassociated Dectin-1 levels following beta-glucan administration. J Pharmacol Exp Ther 318: 540-546, 2006

90. Brown GD, Herre J, Williams DL, Willment JA, Marshall AS and Gordon S: Dectin-1 mediates the biological effects of betaglucans. J Exp Med 197: 1119-1124, 2003.

91. Taylor PR, Tsoni SV, Willment JA, Dennehy KM, Rosas M, Findon H, Haynes K, Steele C, Botto M, Gordon S and Brown GD: Dectin-1 is required for beta-glucan recognition and control of fungal infection. Nat Immunol 8: 31-38, 2007.

92. Ni L, Gayet I, Zurawski S, Duluc D, Flamar AL, Li XH, O'Bar A, Clayton S, Palucka AK, Zurawski G, Banchereau J and Oh S: Concomitant activation and antigen uptake via human dectin-1 results in potent antigen-specific $\mathrm{CD}^{+} \mathrm{T}$ cell responses. J Immunol 185: 3504-3513, 2010.

93. Ma J, Becker C, Lowell CA and Underhill DM: Dectin-1triggered recruitment of light chain 3 protein to phagosomes facilitates major histocompatibility complex class II presentation of fungal-derived antigens. J Biol Chem 287: 34149-34156, 2012.

94. Dragicevic A, Dzopalic T, Vasilijic S, Vucevic D, Tomic S, Bozic B and Colic M: Signaling through Toll-like receptor 3 and Dectin-1 potentiates the capability of human monocyte-derived dendritic cells to promote T-helper 1 and T-helper 17 immune responses. Cytotherapy 14: 598-607, 2012.
95. Bulmer GS, Beneke ES and Stevens JA: Studies on Calvatia gigantea. III. Antitumor substances produced by mycelium from germinated spores and parent basidiocarps. Mycologia 54: 621-625, 1962.

96. Lukas EH, Ringler RL, Byerrum RU, Stevens JA, Clarke DA and Stock CC: Tumor inhibitors in Boletus edulis and other holobasidiomycetes. Antibiot Chemother 7: 1-14, 1957.

97. Tukonaka K, Ohano N, Adachi Y, Tanaka S, Tamura H and Yadomae T: Immunopharmacological and immunotoxicological activities of a water-soluble (1-3)- $\beta$-glucan, CSBG from Candiada spp. Int J Immunopharmacol 5: 383-394, 2000.

98. Suzuki I, Takeyama T, Ohano N, Oikawa S, Sato K, Suzuki Y and Yadomae T: Antitumor effect of polysaccharide griofolan NMF-5N on syngeneic tumor in mice. J Pharmacobiodyn 2: 72-77, 1987.

99. Ren L, Perera C and Hemar Y: Antitumor activity of mushroom polysaccharides: a review. Food Funct 3: 1118-1130, 2012.

100. Borchers AT, Keen CL and Gershwin ME: Mushrooms, tumors and immunity: an update. Exp Biol Med 229: 393-406, 2004.

101. Itoh $\mathrm{H}$, Ito $\mathrm{H}$, Amano $\mathrm{H}$ and Noda $\mathrm{H}$ : Inhibitory action of a $(1 \rightarrow 6)$-beta-D-glucan-protein complex (F III-2-b) isolated from Agaricus blazei Murill ('himematsutake') on Meth A fibrosarcoma-bearing mice and its antitumor mechanism. Jpn J Pharmacol 66: 265-271, 1994.

102. Mizuno M, Morimoto $\mathrm{M}$, Minato $\mathrm{K}$ and Tsuchida $\mathrm{H}$ : Polysaccharides from Agaricus blazei stimulate lymphocyte T-cell subsets in mice. Biosci Biotechnol Biochem 62: 434-437, 1998.

103. Mizuno M, Minato K, Ito H, Kawade M, Terai $\mathrm{H}$ and Tsuchida $\mathrm{H}$ : Antitumor polysaccharide from the mycelium of liquid-cultured Agaricus blazei mill. Biochem Mol Biol Int 47: 707-714, 1999.

104. Pinheiro F, Faria RR, de Camargo JLV, Spinardi-Barbisan ALT, da Eira AF and Barbisan LF: Chemoprevention of preneoplastic liver foci by dietary mushroom Agaricus blazei Murill in the rat. Food Chem Toxicol 41: 1543-1550, 2003.

105. Alves de Lima PL, Delmanto RD, Sugui MM, da Eira AF, Salvadori DM, Speit G and Ribeiro LR: Letinula edodes (Berk.) Pegler (Shiitake) modulates genotoxic and mutagenic effects induced by alkylating agents in vivo. Mutat Res 496: 23-32, 2001.

106. Sugui MM, Alves de Lima PL, Delmanto RD, da Eira AF, Salvadori DMF and Ribeiro LR: Antimutagenic effect of Lentinula edodes (BERK.) Pegler mushroom and possible variation among lineages. Food Chem Toxicol 41: 555-560, 2003.

107. Zhang Y, Mills GL and Nair MG: Cyclooxygenase inhibitory and antioxidant compounds from the mycelia of the edible mushroom Grifola frondosa. J Agric Food Chem 50: 7581-7585, 2002.

108. Prescott SM and Fitzpatrick FA: Cyclooxygenase-2 and carcinogenesis. Biochim Biophys Acta 1470: M69-M78, 2000.

109. Kodama N, Komuta K, Sakai N and Nanba H: Effects of D-fraction, a polysaccharide from Grifola frondosa on tumor growth involve activation of NK cells. Biol Pharm Bull 25 1647-1650, 2002.

110. Lin ZB and Zhang HN: Anti-tumor and immunoregulatory activities of Ganoderma lucidum and its possible mechanisms. Acta Pharmacol Sin 25: 1387-1395, 2004

111. Youn MJ, Kim JK, Park SY, Kim Y, Park C, Kim ES, Park KI, So HS and Park R: Potential anticancer properties of the water extract of Inonotus [corrected] obliquus by induction of apoptosis in melanoma B16-F10 cells. J Ethnopharmacol 121: 221-228, 2009

112. Lavi I, Levinson D, Peri I, Tekoah Y, Hadar Y and Schwartz B Chemical characterization, antiproliferative and antiadhesive properties of polysaccharides extracted from Pleurotus pulmonarius mycelium and fruiting bodies. Appl Microbiol Biotechnol 85: 1977-1990, 2010.

113. Di Luzio NR, Williams DL, McNamee RB, Edwads BF and Kitahama A: Comparative tumor inhibitory and anti-bacterial activity of soluble and particlate glucan. Int J Cancer 24: 773-779, 1979

114. Yoon TJ, Kim TJ, Lee H, Shin KS, Yun YP, Moon WK, Kim DW and Lee KH: Anti-tumor metastatic activity of betaglucan purified from mutated Saccharomyces cerevisiae. Int Immunopharmacol 8: 36-42, 2008.

115. Yamamoto K, Kimura T, Sugitachi A and Matsuura N: Antiangiogenic and anti-metastatic effects of beta-1,3-D-glucan purified from Hanabiratake, Sparassis crispa. Biol Pharm Bull 32: 259-263, 2009. 
116. Ishihara Y, Fujii T, Iijima H, Saito K and Matsunaga K: The role of neutrophils as cytotoxic cells in lung metastasis: suppression of tumor cell metastasis by a biological response modifier (PSK). In Vivo 12: 175-182, 1998.

117. Lee IS and Nishikawa A: Polyozellus multiplex, a Korean wild mushroom, as a potent chemopreventive agent against stomach cancer. Life Sci 73: 3225-3234, 2003.

118. Fujimiya Y, Suzuki Y, Oshiman K, Kobori H, Moriguchi K, Nakashima H, Matumoto Y, Takahara S, Ebina $T$ and Katakura R: Selective tumoricidal effect of soluble proteoglucan extracted from the basidiomycete, Agaricus blazei Murill, mediated via natural killer cell activation and apoptosis. Cancer Immunol Immunother 46: 147-159, 1998.

119. Chihara G, Hamuro J, Maeda Y, Arai Y and Fukuoka F: Antitumor polysaccharide derived chemically from natural glucan (pachyman). Nature 225: 943-944, 1970.

120. Ohno N, Furukawa M, Miura NN, Adachi Y, Motoi M and Yadomae T: Antitumor betaglucan from the cultured fruit body of Agaricus blazei. Biol Pharm Bull 24: 820-828, 2001.

121. Sasaki T, Abiko N, Sugino Y and Nitta K: Dependence on chain length of antitumor activity of $(1 \rightarrow 3)-\beta-D$-glucan from Alcaligenes faecalis var. myxogenes, IFO 13140 and its aciddegraded products. Cancer Res 38: 379-383, 1978.

122. Iino K, Ohno N, Suzuki I, Miyazaki T and Yadomae T: Structural characterization of a neutral antitumour beta-D-glucan extracted with hot sodium-hydroxide from cultured fruit bodies of Grifola Frondosa. Carbohyd Res 141: 111-119, 1985.

123. Furusawa E, Chou SC, Furusawa S, Hirazum A and Dang Y: Antitumor activity of Gonoderma lucidum and edible mushroom, on interaperitoneally implanted Lewis lung carcinoma in synergeneic mice. Phytother Res 6: 300-304, 1992.

124. Gelderman KA, Tomlinson S, Ross GD and Gorter A Complement function in $\mathrm{mAb}$-mediated cancer immunotherapy. Trends Immunol 25: 158-164, 2004.

125. Akramiene D, Kondrotas A, Didziapetriene J and Kevelaitis EP. Effects of beta-glucans on the immune system. Medicina (Kaunas) 43: 597-606, 2007.

126. Cheung NV and Modal S: Oral (1-3),(1-4)- $\beta$-D-Glucan synergizes with antiganglioside GD2 monoclonal antibody $3 \mathrm{~F} 8$ in the therapy of neuroblastoma. Clin Cancer Res 8: 1217-1223, 2002.

127. Sier CFM, Gelderman KA, Prins FA and Gorter A: Beta-glucan enhanced killing of renal cell carcinoma micrometastases by monoclonal antibody G250 directed complement activation. Int J Cancer 109: 900-908, 2001.

128. Modak S, Koehne G, Vickers A, O'Reilly RJ and Cheung NV: Rituximab therapy of lymphoma is enhanced by orally administered (1-3),(1-4)-D- $\beta$-glucan. Leuk Res 29: 679-683, 2005.
129. Hong F, Yan J, Baran JT, Allendorf DJ, Hansen RD, Ostroff GR, Xing PX, Cheung NK and Ross GD: Mechanism by which orally administered beta-1,3-glucans enhance the tumoricidal activity of antitumor monoclonal antibodies in murine tumor models. J Immunol 173: 797-806, 2004.

130. Liu J, Gunn L, Hansen R and Yan J: Combined yeast-derived beta-glucan with anti-tumor monoclonal antibody for cancer immunotherapy. Exp Mol Pathol 86: 208-214, 2009.

131. Huang H, Ostroff GR, Lee CK, Agarwal S, Ram S, Rice PA, Specht CA and Levitz SM: Relative contributions of dectin-1 and complement to immune responses to particulate $\beta$-glucans. J Immunol 189: 312-317, 2012.

132. Xiang D, Sharma VR, Freter CE and Yan J: Anti-tumor monoclonal antibodies in conjunction with $\beta$-glucans: a novel anti-cancer immunotherapy. Curr Med Chem 19: 4298-4305, 2012.

133. Ina $\mathrm{K}$ and Ando $\mathrm{T}$ : The use of Lentinan for treating gastric cancer. Anticancer Agents Med Chem: Oct 18, 2012 (Epub ahead of print).

134. Kataoka H, Shimura T, Mizoshita T, Kubota E, Mori Y, Mizushima T, Wada T, Ogasawara N, Tanida S, Sasaki M, Togawa S, Sano H, Hirata Y, Ikai M, Mochizuki H, Seno K, Itoh S, Kawai T and Joh T: Lentinan with S-1 and paclitaxel for gastric cancer chemotherapy improve patient quality of life. Hepatogastroenterology 56: 547-550, 2009.

135. Chen J, Zhang XD and Jiang Z: The application of fungal betaglucans for the treatment of colon cancer. Anticancer Agents Med Chem: Dec 24, 2012 (Epub ahead of print).

136. Hamuro J and Chihara G: Effect of antitumour polysaccharides on the higher structure of serum protein. Nature 245: 40-41, 1973.

137. Soto ER, Caras AC, Kut LC, Castle MK and Ostroff GR: Glucan particles for macrophage targeted delivery of nanoparticles. J Drug Deliv 2012: 143524, 2012.

138. Huang H, Ostroff GR, Lee CK, Specht CA and Levitz SM: Robust stimulation of humoral and cellular immune responses following vaccination with antigen-loaded beta-glucan particles. MBio 1: e00164-10, 2010.

139. Lehtovaara BC and Gu FX: Pharmacological, structural and drug delivery properties and applications of $1,3-\beta$-glucans. J Agric Food Chem 59: 6813-6828, 2011.

140. Browder W, Williams D, Lucore P, Pretus H, Jones E and Mcnamee R: Effect of enhanced macrophage function on early wound-healing. Surgery 104: 224-230, 1988

141. Portera CA, Love EJ, Memore L, Zhang L, Müller A, Browder W and Williams DL: Effect of macrophage stimulation on collagen biosynthesis in the healing wound. Am Surg 63: 125-131, 1997. 